\title{
Golf cart related injuries in a North Carolina island community, 1992-4
}

\author{
Kristi Tolo Passaro, Thomas B Cole, Peter D Morris, Donald L Matthews Jr, William R \\ Mac Kenzie
}

\begin{abstract}
Objectives and methods-The use of electric golf carts for roadway transportation is increasing in many regions of the United States, but injuries associated with the operation of these vehicles have not been previously described. In response to reports of golf cart related injuries in a North Carolina island community, we reviewed ambulance call report (ACR) information to identify and describe all injuries related to golf cart operation in this community in 1992-4. We also conducted telephone interviews with the subset of injured people who consented to be contacted.
\end{abstract}

Setting-Bald Head Island, North Carolina.

Results-Twenty two people were included in the case series, and $55 \%$ of these provided interview information to supplement ACR data. Fifty nine per cent of the 22 injured people were injured when they fell from a moving golf cart; of those injured in this manner, all with available information on seating position were passengers (rather than drivers). Eighty six per cent received immediate medical treatment at a mainland hospital. Thirty two per cent of injury incidents occurred among children aged 10 or younger. Forty per cent of injured adults were known to have been drinking alcohol before their injuries occurred, while alcohol was not known to have been involved in any of the children's injuries (in terms of drinking either by children or by accompanying adults).

Conclusions-In settings where golf carts are used for road transportation, their users and traffic safety officials should be aware of potential safety hazards associated with the use of these vehicles, and installation of appropriate occupant restraints should be considered seriously. (Injury Prevention 1996; 2: 124-125)

Keywords: injuries, golf carts, transportation, seat belts.

According to golf cart manufacturing officials, the use of golf carts for roadway transportation and personnel transport is increasing in a variety of non-golf course settings, including residential retirement and beach communities, entertainment parks, industrial plants, corporate campuses, prisons, and military bases (Michael Alexander, Club Car, personal com- munication). While some of these settings typically involve only adults, the increasing use of golf carts in certain types of settings (for example, residential beach communities) is likely to provide additional opportunities for children to be exposed to this form of transportation. In this report, we describe an investigation of golf cart related injuries among both children and adults in a North Carolina island community. To our knowledge, this investigation is the first of its kind.

\section{Methods}

At the request of island officials, we conducted an investigation of golf cart related injuries on Bald Head Island, North Carolina, where fourpassenger electric golf carts (hereafter referred to as 'golf carts') represent the primary means of vehicular transportation. This island is accessible only by boat, and the use of gas powered vehicles on the island is restricted to emergency and maintenance purposes.

We defined a golf cart related injury as one that occurred in association with golf cart operation on the island from January 1992 through December 1994 for which a standard ambulance call report (ACR) form was filed. ACR forms are completed for every incident occurring on the island in which a responding public safety officer provides emergency medical care. Complete ACR files were not available for years before 1992. Injured people meeting the case definition were identified through a review of ACR files. A letter explaining the investigation was mailed to each of them (or to the parents of those under the age of 18); this mailing also included a consent form requesting permission to contact the person by telephone. People who did not return their consent forms within four weeks of the initial mailing were sent a second letter and consent form.

During our investigation, we collected observational information on golf cart design, roadway characteristics, and traffic sign placement. We also used a hand held radar unit to record speeds of consecutive golf carts on two main island roadways at several times over a two day period.

\section{Results}

There were 23 people injured in 1992-4 whose ACR forms mentioned golf carts. Of these, nine adults and the parents of four children agreed to be interviewed. Based on interview information, one child's injury was found not to meet the case definition because it involved a 
Injury circumstances and seating position for 22 people with golf cart related injuries, Bald Head Island, NC, 1992-4

\begin{tabular}{lll}
\hline Injury circumstances & No $(\%)^{\star}$ injured & Seating positions $\dagger$ \\
\hline Fell off moving golf cart & $13(59)$ & 4 FP, 5 RP, 4 U \\
Caught between two golf carts or & $4(18)$ & $1 \mathrm{D}, 1 \mathrm{RP}, 1 \mathrm{NA}, 1 \mathrm{U}$ \\
between golf cart and wall & $2(9)$ & $1 \mathrm{D}, 1 \mathrm{P}$ \\
Golf cart overturned & $1(5)$ & $1 \mathrm{P}$ \\
Stepped off moving golf cart & $2(9)$ & $2 \mathrm{U}$
\end{tabular}

$\star$ Percentage of all injured people $(n=22)$ whose injuries occurred in a particular type of circumstances.

†Seating position of injured person: $D=$ driver; $F P=$ front seat passenger; $R P=$ rear seat passenger; $\mathrm{P}=$ passenger, not otherwise specified; $\mathrm{NA}=$ not applicable; $\mathrm{U}=$ unknown.

stationary golf cart. Thus, a total of 22 injured people were included in the final case series, and interview data were available to supplement ACR information for $12(55 \%)$.

The 22 golf cart related injuries occurred in April through November of each year, with the greatest number (six, or $27 \%$ ) reported in August. Ten $(45 \%)$ occurred on Fridays and Saturdays. Sixteen (73\%) of the injured people were female. The median age of the seven injured children was 6 years (range $2-10$ ), and that of the 15 injured adults was 34 years (range 16-73). All seven children were injured during daylight hours, whereas nine $(60 \%)$ of the adults were injured between $8 \mathrm{pm}$ and 2 am. None of the injuries occurred on the island's golf course.

Injury circumstances and seating positions are listed in the table. Thirteen people (59\%) were injured when they fell from a moving golf cart. Of the 14 people with available information on seating position, $12(86 \%)$ were passengers. At least six $(40 \%)$ of the 15 injured adults had drunk alcohol within a two to three hour period before their injuries occurred. Of these, all five with available information on seating position were passengers in golf carts operated by drivers who had also been drinking alcohol.

Nineteen $(86 \%)$ of the 22 injured people received immediate medical care at a mainland hospital. Thirteen $(59 \%)$ sustained head or face injuries, ranging in severity from a small laceration to a skull fracture. Two people with head injuries lost consciousness and were hospitalized overnight for two and 10 days, respectively.

The typical four-passenger golf cart used on the study island has a rear facing back seat. None of the golf carts were observed to have seat belts or other passenger restraints in either the front or back seats. When vehicle speed was measured for 31 golf carts, the mean speed was $14 \mathrm{miles} / \mathrm{hour}(\mathrm{mph})$, and only two golf carts were being driven faster than the $18 \mathrm{mph}$ speed limit (both at $22 \mathrm{mph}$ ). Neither excessive vehicle speeds nor hazardous roadway characteristics appeared to contribute to the injuries in the case series.

\section{Discussion}

Golf cart related injuries are neither uncommon nor benign events. Data from the National Electronic Injury Surveillance System indicate that an estimated 14000 people with golf cart related injuries were treated in emergency departments nationwide in 1992-4, of whom approximately $45 \%$ were injured when they fell from a golf cart (Nancy Rytina, US Consumer Product Safety Commission, personal communication). In this case series, $59 \%$ of the 22 people treated for golf cart related injuries on the study island in 1992-4 were injured when they fell off a moving golf cart.

Our findings suggest the need for occupant restraints in golf carts when these vehicles are used as a means of road transportation. Currently, occupant restraints are not routinely installed in golf carts by manufacturers. Many dealers and repair shops, however, will install standard automobile lap belts in golf carts at the request of owners. We are unaware of instances in which passive restraints - such as a lap bar that must be pulled into place before a golf cart can be operated - have been installed in golf carts, but the possibility of using these devices should also be explored.

In 1995, the California Legislature enacted a law allowing any city or county in the state to adopt a golf cart transportation plan. Golf carts used for transportation under such plans are required to be equipped with seat belts and other safety features. To date, at least two California cities have implemented golf cart transportation programs.

In our series, at least six $(40 \%)$ of the 15 injured adults had been drinking alcohol before they were injured, and most of these were riding with drinking drivers. As North Carolina laws regarding driving while impaired are difficult to enforce on the island, due in part to the absence of on-site alcohol breath testing equipment, additional preventive measures for injuries occurring among drinkers should be considered. Intoxicated drivers of standard motor vehicles have been shown to be less likely to wear seat belts than drivers who are not intoxicated. ${ }^{1}$ If golf cart drivers and passengers who have been drinking are similarly unlikely to use seat belts, passive restraints may provide more protection to these occupants. Such restraints might be less effective than seat belts (or child safety seats) in protecting child passengers, however. Thus, the characteristics of golf cart occupants in a particular setting must be considered in making decisions about occupant restraint systems.

As the use of electric golf carts for road transportation expands in non-golf course settings (including residential and recreational settings that provide opportunities for children to be exposed to this form of transportation), and as the maximum speeds of these vehicles increase, those responsible for traffic safety in these settings will need to be aware of potential safety hazards associated with golf cart use. In particular, occupant restraints appropriate to the characteristics of users should be installed in all golf carts used for road transportation.

The authors thank Nancy Rytina and Ronald Medford, US Consumer Product Safety Commission, for providing data from the National Electronic Injury Surveillance System about golf cart related injuries. The authors also thank Sam Sherrill, Linda Matthews, and Trish Sherrill for assistance with data collection.

1 Foss RD, Beirness DJ, Sprattler K. Seat belt use among drinking drivers in Minnesota. Am $\mathcal{F}$ Public Health 1994; 84: $1732-7$. 